\title{
PUBLIC FINANCIAL LAW IN DIGITAL ECONOMY
}

\section{JAVNO FINANCIJSKO PRAVO U DIGITALNOJ EKONOMIJI}

\author{
Imeda A. Tsindeliani \\ Department of Financial Law, Russian State University Justice, Moscow, Russia \\ Odjel za financijsko pravo, Rusko državno sveučilište za pravo, Moskva, Rusija
}

\section{Abstract}

Finance has become an active area of the application of these technologies. As a result, the emergence of new institutions and the modernization of the existing ones, based on new technological breakthrough of humanity, which undoubtedly affect already existing institutions, and which are subject to change under their influence. The aim of this paper is to define the list of unresolved issues in the theory of the financial law that exist in relation to the nature of the technologies used and innovation ("fintech") in the field of the public finance and the means of legal regulation of the public finance.

\section{INTRODUCTION}

The modern State can fully realize practically none of its intended purpose without a stably functioning financial system of the State. The balanced and effectively interacting segments of the public and private finances are theoretically the financial system of the State. In the economic literature, examination of the financial systems of the State is traditionally conducted through two approaches: functional and structural $/ \mathbf{1}$. It should be noted that in the foreign economic literature different terms are used to refer to two main types of the financial systems (markets): "financial system based on banks" (bank based financial system) and "financial

\section{Sažetak}

Financije su postale aktivno područje primjene ovih tehnologija. Kao rezultat toga, pojavljuju se nove institucije i moderniziraju postojeće, temeljene na novom tehnološkom prodoru čovječanstva, koji nesumnjivo utječe na već postojeće institucije, a koje su pod utjecajem promjena. Cilj ovog rada je definirati popis neriješenih pitanja $u$ teoriji financijskog prava koja postoje $\mathrm{u}$ odnosu na prirodu korištenih tehnologija i inovacija („fintech“) u području javnih financija i sredstava pravnih reguliranja javnih financija.

system based on securities market" (market based financial system); "relationship-based financial markets" and "direct access financial markets" (arm's length financial markets), or, briefly, "banking" and "market"/2/.

The examination of the financial system of the State in the framework of the structural approach that prevails in the literature is carried out through an analysis of the aggregate of the institutions and markets that provide services to private and public entities $/ 3 /$. The examination of the financial system of the State is carried out through financial institutions and the markets in which they operate, and the available infrastructure. In turn, within the framework of the functional approach, the financial system is 
examined through the prism of the following segments: public finance, corporate finance and household finance, the latter itself (corporate and household finance) form the private finance segment.

The characteristic of the modern financial system of Russia and the very nature of modern finance causes undoubted interest.

Describing the modern financial system of Russia, researchers come to the following conclusions:

- the financial system, as a system of the market country, hasn't been completed, since it hasn't completely moved to the market and now it is halfway to a developed modern market. Since the finance are monopolized, in fact there is a nationalization of the part of the financial system;

- permeation from top to bottom of the ideas of the tax orientation in general, the high centralization of the finance;

- budget money - the most inefficient money in the State

- the absence of large cash funds in addition to public finance as sources of long-term money /4/. The above mentioned characteristics of the modern financial system of the State show that its effective functioning as a factor ensuring the stable development of the State has not been fully realized. It should be noted that, up to now, it hasn't been possible to ensure high efficiency of expenditures of the public legal entities and the increase of the target efficiency criteria ensuring the growth of socio-economic development. In the Russian Federation, along with the current system of taxes and fees, a parallel tax system has been formed. It is represented by compulsory payments and is not inferior to the current tax system by its fiscal burden. In fact, there are two parallel systems in the country: a system of taxes and fees, concentrated in the Tax Code of the Russian Federation, and a system of mandatory payments (quasi-taxes), scattered in the separate regulatory legal acts, which in their number exceed the entire set of applicable federal, regional and local taxes and fees. Taxes and fees have received a unified regulatory framework in the legislation on taxes and fees, and the regulatory nature of them is adequately disclosed, but there is no uniform regulatory framework for compulsory payments that are not included in the current system of taxes and fees, but they are not inferior to tax payments $/ 5 /$.

Existing researches into the problems of the public finance efficiency examine it through two factors that determine the functions of the public welfare, namely, vertical and horizontal justice that underlies the State's tax instruments $/ 6 /$.

The system of public finances of the State itself is based on three levels: public finances of the federation, public finances of the subjects of the federation and public finances of municipalities. The modern theory of the public finance assumes that public finance has the following basic functions: distributive, redistributive, and stabilization functions /7/. The realization of these functions necessitates the use of various tools, including within the budget, fiscal and monetary tools. The effective combination of these tools allows to ensure the maximum satisfaction in the needs of the public goods.

Public and private finance, being interconnected and interdependent segments of the financial system of the State, on the one hand, are economic phenomena, but at the same time it cannot be denied that their functioning and structural features are directly related to the legal and political system of the State. Therefore, it is necessary to say directly that the financial system of the State and its segments are formed and function not only as an economic phenomenon, but also as a legal and political phenomenon.

Modern economic theory defines finance as a system of the monetary relations associated with the formation, distribution and use of the centralized funds of the public legal entities to perform the functions intended for them and decentralized funds of the economic entities and households /8/. According to Sazhina M.A., the monetary essence of the modern finance is replaced by titles, which are given a virtual character. In other words, finances have become virtual ones. It has become a consequence of the new quality of economic relations is virtualization of the economy, where the product as a basic object of the relations has lost the priority, 
and financial assets have become the main priority. A vivid example of changes in the nature of the finance is adopted by the Bank of Russia "Main Directions for the Development of Financial Technologies for the period 2018-2020"2. In particular, modern trends are associated with the stimulation and development of financial technologies, including:

- low marginality of banking services;

- transformation by the financial market participants their business models and the desire to create ecosystems;

- increase of the financial services penetration due to their digitalization;

- loss by banks of the monopoly on the provision of traditional (payment and other) services, as well as the acquisition by non-financial organizations of a significant role in the financial market;

- banks' desire for partnerships with startups and technology companies. The most perspective financial technologies are considered:

- Big Data and data analysis;

- mobile technologies;

- artificial intelligence;

- robotization;

- biometrics;

- distributed registries;

- cloud technologies.

The development of the financial technologies modernizes traditional areas:

- payments and transfers: online payment services, online transfer services, P2P2 currency exchange, B2B3 payment and transfer services, cloud offices and smart terminals, mass payment services;

- financing: P2P consumer loans, P2P business loans, crowdfunding;

- capital management: robo-advancing, financial planning programs and applications, social trading, algorithmic trading, target savings services, and others.

It is generally recognized that our society and the very humanity itself is at a new stage of the development, which is regarded as the fourth industrial revolution, the fruits of which we use every day /9/. In fact, this stage of human development can be called the era of new technologies. Technologies that have already began to influence all spheres of the human life and finances have become an active area of the application of these technologies. As a result, the emergence of new institutions and modernization of the existing ones. The development of new economic institutions, based on new technological breakthroughs of the humanity, undoubtedly affect the existing institutions, which are the subject to change under their influence. Even such a category as money, which is at the heart of finance, has already been losing its material forms of the expression and regulating properties. Alternative tools appear in the economy, which are ready, if not completely, then partially, to be an alternative to this traditional institution. As a result, any alternative to money and the mechanisms of money circulation will affect the basic instrument for regulating economic relations and the financial system of the State as a whole - a monopoly on the issue of currency.

The modern economy is transformed into a digital economy at different rates. In the modern literature various definitions of the category digital economy - are given. In particular, Lapidius L. V. defines it as a set of the relations developing in the process of production, distribution, exchange and consumption, based on the online technologies and aimed at the meeting the needs of life benefits, involving the formation of new ways and methods of managing and requiring effective tools government regulation $/ \mathbf{1 0} /$.

The development of the new technologies and the transition of the mankind to a new stage of the industrial revolution encourages States to conduct a new policy, which is aimed at the transformation of many public institutions and processes. New technologies and the economic relations developing on their basis equally apply not only to private actors, but also directly come into contact with the activities of the State and institutions related to its functioning. In this connection, the Government of the Russian 
Federation has approved the program for the development of the digital economy of the Russian Federation, in which data in digital form is a key factor of the production in all areas of socio-economic activity, which increases the country's competitiveness, quality of the life of the citizens, ensures economic growth and national sovereignty ${ }^{3}$. Actually, the realization of this program should make the Russian State a competitive participant in the global digital market, since the new industrial revolution and the new technologies introduced by it pose to the State and society, in general, the need to carry out transformations of the entire socioeconomic system. As a result, new technological products that are not exhaustive are designated, in particular, by such phenomena as:

- big data;

- neurotechnology and artificial intelligence;

- systems of distributed registry;

- quantum technologies;

- new production technologies;

- industrial internet;

- components of robotics and sensorics;

- wireless technology.

- technologies of virtual and augmented reality, which touch the sphere of public finance.

- quantum technologies;

- new production technologies.

At the same time, the influence of the new technological phenomena can't only partially, but also globally change the traditional elements that form the entire financial system not only of a specific State, but also the global system of the global finance, and not only can, but also are changing it in real time.

The blockchain technology and derivative products associated with its use, such as cryptocurrency has become the most well-known and universally mentioned phenomenon of the new technological products. The blockchain technology itself is a distribution registry consisting of interconnected blocks of a transaction.

\footnotetext{
${ }^{3}$ The decree of the President of the Russian Federation from 09.05.2017 N 203 "Strategy of information society development in Russian Federation to 2017 - 2030" // Sz the Russian Federation. 15.05.2017. N 20. article 2901; resolution of the Government of the Russian Federation from 28.08.2017 N 1030 "About control system implementation of "Digital economy of the Russian Federation" (together with "Rules
}

Transaction blocks are called registry nodes or nodes. In general, they represent a decentralized database designed to store and confirm the reliability of information /11/. Modern studies on the use of modern technologies in the economy and, in particular, technology in the field of finance, conventionally referred to as "financial technologies", indicate the absence of a legal definition of such a term, but also the absence in national jurisdictions of clearly developed concepts of legal regulation of this sphere /12/. The Russian Federation is only at the beginning of the way to develop a national legal policy to regulate the sphere of "financial technologies". The studies of the development of the network law in the legal system of the State are of great interest for the development of the legal regulation of "financial technologies".

Nevertheless, it is possible to express our views on those segments of public finances, which, undoubtedly, will undergo modernization due to the laws of the development of the digital economy as an economy, new technologies. It should be recognized that none of the public finance segments will avoid the modernization impact of the digital economy, namely:

- The monetary system of the State and its operation;

- the budget system of public legal entities;

- tax system of public legal entities;

- the banking system of the State, etc.

\section{RESULTS}

\section{Cryptocurrency}

The Financial Stability Board of the Basel Committee on Banking Supervision defines "fintech" as "technologically supported financial innovations that contribute to the creation of new business models, applications, processes and products that have the potential to have a material impact on the traditional approaches of financial markets and institutions, as well as

of development, monitoring and control of the implementation of action plans for the implementation of the "Digital economy of the Russian Federation") // Sz the Russian Federation. 04.09.2017. No. 36. article 5450; Order of the Government of the Russian Federation of 28.07.2017 N 1632-p $<$ on approval of the program "Digital economy of the Russian Federation"> // NW. 07.08.2017. N 32. article 5138. 
the procedure for providing financial services." 4

The consequences of the introduction of new digital technologies, the emergence and development of new objects based on the public blockchain of such cryptocurrencies like Bitcoin, Lightcoin, Ethereum, etc. (hereinafter referred to as "cryptocurrency") are very relevant, there is a need for legal regulation as tools and relations arising from their use in general. There is a rather lively discussion about the legal nature of cryptocurrency, while one of the most important aspects is the qualification of cryptocurrency as an object of civil rights, which creates conditions for the legal regulation of operations that are subject to cryptocurrency, which will allow for both legal regulation and other no less important relationship issues arising from the use of cryptocurrency. Currently, most countries are trying to deal with the status of cryptocurrency and introduce legal regulation that meets the interests of the State and business.

Cryptocurrency is money. As known, the concept of "money" is an economic substance, thanks to the work of Friedrich A. Hayek, McConnell KR, Brue, S. L., M. Friedman, J. M. Keynes, L. Harris /13/. Money is a special commodity that is the universal equivalent of the value of other goods and services. Modern economics allocates five functions of money:

1. Measure cost. Money makes it possible to estimate the value of goods by setting prices.

2. Means of circulation. Money plays the role of the intermediary in the exchange process.

3. Means of payment. The function of money, allowing the time of payment does not coincide with the time of payment, that is, when goods are sold on credit.

4. Means of accumulation and savings. The ability of money to participate in the process of the formation, distribution, redistribution of the national income, formation of the savings of the population.
5. The function of world money. It is manifested in the relationship between economic entities: States, legal entities and individuals located in different countries.

It is believed that money performs its task only with the participation of people who use the possibilities of money. It is people who can determine the prices of goods, use money in the processes of realization and payments, and also use them as a means of accumulation. Thus, theoretically, any object that performs these functions can be considered money.

Cryptocurrency is the equivalent of cash. Using the example of the most famous cryptocurrency Bitcoin - it can be argued that this is an electronic digital equivalent of cash or an institution that will eventually be able to force out cash. If the authenticity of the cash is verified through watermarking, security thread, microchip, with the help of special technical means, etc., in the case of cash, there is no registry that contains transaction records (therefore certain limitations of cash payments, and there is also a centuries-old problem with their counterfeit of both coins and banknotes), in the case of cryptocurrency - bitcoins, the transaction register guarantees their authenticity. In his work, Frederick. A. Hayek "Private Money", even in 1975, proposed a radically new way to achieve monetary stability - a system based on the competition of parallel private currencies. His idea was simple: such currency should be recognized as an ordinary commodity and, accordingly, produced in a market way. In his opinion, "only those currencies will remain that will best perform the functions of money: serve as a means of payment and save their value over time."

Cryptocurrency does not fall under the concept of the electronic money, because it has a different mechanism of occurrence. Cryptocurrency is issued through the decentralized emission. No intermediates are needed for its transfer from one entity to another (any special subjects banks, clearing centers, etc.). There are no territorial boundaries for transfer. It is possible to

\footnotetext{
${ }^{4}$ See: Advisory document of the Basel Committee on banking supervision on the impact of FINTECH developments
}

on banks and Supervisory authorities dated 31.10.2017 // URL: https://www.bis.org/bcbs/publ/d415.pdf. 
convert into fiat currency ${ }^{5}$ and there is the impossibility of canceling the transaction. The disclosure of the concept of "cryptocurrency" through the concept of "digital financial asset", I believe, is not entirely successful, since there is some misunderstanding in the difference between such concepts as cryptocurrency and digital assets. Although it is possible, of course, to say that each cryptocurrency is a digital asset in its essence, but they differ in their management method. There are many differences between financial instruments. Digital asset exists in binary format, i.e. binary files are opposed to text files, while text files are a special case of binary files, thus, in the broad sense of the word, any file fits the definition of a binary file. Cryptocurrency is a binding right. According to the legal construction, the rights of obligation are relative legal relations: there are specific participants who are obliged to a certain behavior pursuing a property interest (as opposed to an absolute legal relationship, in which an authorized person is opposed by an unspecified number of persons, for example, in property legal relations, operational management), i.e. in the legal obligations, the obligated person is always opposed to the entitled person.

The relations, which subject is a cryptocurrency, are built by joining the participant to the trading platform on which the cryptocurrency is circulated. In any case, to buy a cryptocurrency, you need to get your own cryptocurrency wallet. A cryptographic cryptocell is a special program that stores keys for transactions performed.

Having analyzed various sources, you can define the concept of a cryptocurrency as follows: it is a digital (virtual) currency, the creation and control of which is based on cryptographic methods (mathematical algorithms), in relation to which full decentralization is established (no external or internal administrator in the network), which guarantees (confirming) the correctness of the system operations, including the

\footnotetext{
${ }^{5}$ Fiat money (from lat. Fiat-decree, the indication "so be it") - is the money, the nominal value of which is established and guaranteed by the State, regardless of the value of the material from which the money is made, or in the vault of the Bank (unsecured money).
}

inability to influence the transactions of the system participants. The reliability of the transactions is ensured in the network by Blockchain technology (replicated distributed database distributed registry technology), the algorithms of which allow combining transactions into "blocks" and adding them to the "chain" of existing blocks to ensure that the base of the chain of transaction blocks is invariable using elements of cryptography and successive hashing $^{6}$. Continuity is provided by including in the current block the hash sum of the previous block, which does not allow changing the block without changing the hashes in all subsequent blocks. Mathematical calculations act as a security as a kind of value of the physical world.

Thus, cryptocurrency is a completely new object of the legal regulation, based on fundamentally different approaches that require excellent legal regulation both at the level of the domestic law and at the level of international law. That's why, it will be necessary to define the conceptual apparatus, provide different legal regulation depending on the cryptocurrency function performed (for example, the instability of the cryptocurrency exchange rate carries negative consequences for the purposes of its use in the investment asset (for accumulation purposes) as units of measure and income, as there are certain difficulties for current cryptocurrencies in the form of interest income, since at present cryptocurrency profitability is reduced to speculative income or the cost of a fall; creating conditions for cryptocurrency competition, legal grounds and conditions, and the organization of cryptocurrency mining activities, i.e. creating rules, that protect both private law and public law interests, ensuring national security, in connection with which it is necessary to identify the subjects and provide for responsibility in the event of a possible system failure, authorized or unauthorized changes to the programe code, and also arising in connection with this consequences in the system and the procedure for

\footnotetext{
${ }^{6}$ Hashing is a mathematical transformation of the information. Hashing algorithms are used to verify the integrity and authenticity of the files.
} 
their elimination and restoration of the legal balance.

There is a lot of work to be done in a fairly short time. The world does not stand still and at present there are polar situations where, on the one hand, rapidly developing information technologies are being introduced in all spheres of the life of the society and individual, on the other hand, the lack of timely prepared legal mechanisms, the adoption of which can be late effect, when not the State will control the system, but the system of the State, the creation of a substance competing with public order, through the existence of parallel systems, which can lead to a strong competition and effective development, or vice versa, to stop it. Humanity constantly tried to understand, review the form and role of money. We believe that the task of the current generation is to explain the need and need to transform money into a crypto-virtual form.

Accordingly, this affects the functioning of public finances. As a result, this causes the modernization of the legal regulation of the public finances. A special place in the modernization of the legal regulation belongs to the rules of the public financial law. It seems that in the system of the public financial law, a large group of rules is formed, which form the totality of legal institutions that are transformed into a subbranch of the public financial law - the issue law.

\section{Financial Law System}

The interest in the researching of the financial law system as a branch of the law is due to a variety of the circumstances, primarily the active development of legislation governing public finances, the modernization of the State's economic system in general, and the State's financial system in particular. The available monographs show that this problem was and has been remaining an urgent and called for in the field of the scientific researches /14/. The undoubted interest is caused by the approaches of the researchers to the elements that form the system of the branch of the financial law and to the very institutionalization of the branch of law. According to N. Kazantsev, financial law cannot be reduced to a tree structure, in which many different hierarchical subsystems can be distinguished, having a dendritic (tree) form, which is not a mono-hierarchical, but a multihierarchical system, where the highest institution in one hierarchy is lower, on the other - mediating relations with other institutions of the financial law. It is proposed to consider the institute of the financial jurisdiction of the State as such institution.

Kostyukov A.N. notes that the system of the financial law is a body of the parts and elements of the financial law, characterizing its internal structure and isolating it from other branches of the law. The system of the financial law itself is expressed in combining elements of a single legal nature into a structurally-ordered holistic unity, possessing relative independence, stability, autonomy of functioning and interaction with the external environment $/ \mathbf{1 5} /$. In this case, the mentioned author identifies the grouping of the elements of the financial law system for a number of reasons. In particular, the horizontal structure of the branch of the financial law is characterized by the following elements: financial and legal rules, financial and legal institutions, forming sections and subsectors, which are combined in part of the financial law. Along with the horizontal division of the industry, the said author highlights the vertical construction, which is based on the legal force of financial and legal regulatory material. Based on the analysis, A. Kostyukov represents a system of the inancial law, consisting of two parts: the general and the specific. At the same time, the general part includes the following institutions: rules of the financial law, financial and legal status of the subjects of the financial law, financial relations, legal facts in the financial law, institution of the financial control. The special part is represented by the indicated author consisting of a sub-branch of budget and tax law, as well as the following sections:

- State (municipal) revenues;

- State (municipal) expenses;

- banking law;

- insurance activity;

- currency regulation;

- monetary circulation and settlements;

- auditing activities;

- State loan; 
- legal regulation of the enterprise finance. In the researches is noted the need to consider the financial law system not only as a horizontal system, but also as a vertical system.

Kazantsev N. M. defines the system of the financial law, consisting of the following sub-sectors:

- mining, production and turnover of the precious metals and stones;

- emissive (bank notes, securities, financial derivatives);

- credit and banking regulation;

- currency regulation;

- accounting;

- tax;

- budget;

- investment;

- insurance;

- financial and estimated;

- regulation of the financial markets;

- collection;

- supervisory and control.

As you can see, the scientists' view of the modern system of the financial law, as a branch of law, does not differ in the uniformity. Scientific ideas about the system of financial law and the elements of its forming are undoubtedly connected closely with the modern legal thinking and well-established conceptual approaches. It can even be said that a schematic approach to the use of the system-structural approach is common.

In the conditions of the development of the digital technologies and the introduction of "fintec" into the sphere of the public finance, it also entails the modernization of the public financial law institutions. The legal means of regulating the most important segments of the public finances are being modernized - the budget system, the tax system, the monetary system, the banking system, and public securities. Accordingly, the structure of the public financial law is being modernized, since the introduction of the new technologies requires a substantial modernization of legal instruments that ensure the regulation of the public finances. The modern system of the public financial law can be defined through the following elements - the principles of the public financial law, rules of the public financial law, institutions of the public financial law and their associatios. The modern system of the public financial law is represented by such entities as budget law, tax law, emission law, financial control law and public banking law.

\section{CONCLUSION}

Humanity is at a new stage of its development, which is regarded as the fourth industrial revolution. This stage of the human development can be called the era of new technologies, which are already beginning to influence all spheres of human life. Finance has become an active area of the application of these technologies. As a result, the emergence of new institutions and the modernization of the existing ones, based on new technological breakthroughs of the mankind, undoubtedly affect the already existing institutions, which are subject to change under their influence. Money, which is at the heart of the finance, is already losing its material forms of the expression and regulating properties. The alternative tools are emerging in the economy. They are ready to act as alternatives to this traditional institution. The alternative to money and monetary mechanisms will affect the basic instrument for regulating economic relations and the financial system of the State as a whole - a monopoly on the issue of currency. The transition of the humanity to a new stage of the industrial revolution encourages States to implement a new policy that aims to transform many public institutions and processes. At the same time, the impact of new technological phenomena is on the financial system not only of a specific State, but also on the global system of the global finance. As a result, the institutional structure of the public financial law and the legal means of the regulating of the public finances are changing. The modern system of the public financial law can be defined through the following elements - the principles of the public financial law, rules of the public financial law, institutions of the public financial law and their associations. The modern system of the public financial law is represented by such entities as budget law, tax law, emission law, financial control law and public banking law. 
/1/ Ivanov, V. V., Pokrovskaya, N. V. (2018). China's financial system. The textbook (pp. 13-15). Moscow: Prospect.

/2/ Smyslov, D. V. (2006). Financial institutions and economic development: (Digest of articles) (pp. 13-15). Russian Academy of Sciences, Institute of World Economy and International Relations of RAS. Moscow: IMEMO RAN.

/3/ Van Horn, G.K. (2003). Fundamentals of financial management: TRANS. with English (pp. 34). M.: Finance and statistics.

/4/ Aganbegyan, A. G. (2018). Finance, budget and banks in new Russia (pp. 45-98). M. Publishing House "Delo" Ranepa.

/5/ Tsindeliani, I.A.M. (2018). Financial and legal regulation of the mandatory payments to the Federal budget of the Russian Federation (pp. 5-6). Ed. Prospect.

/6/ Atkinson, E. B., Stiglitz, J.E. (1995). Lectures on economic theory of the public sector: Textbook (pp. $474-485)$. M. Aspect press.

/7/ Musgrave, R.A., Musgrave, P.B. (2009). Public Finance: theory and practice (pp. 20-21). M. : Business Atlas.

/8/ Sazhina, M.A. (2018). Nature of modern Finance: monograph (pp. 14). Moscow: Publishing House "FORUM": INFRA-M.
19/ Schwab, K., Davis, N. (2018). Technologies of the Fourth industrial revolution (pp. 29). Moscow: Eksmo.

/10/ Lapidus, L.V. (2018). Digital economy: e-business and e-Commerce management: monograph (pp. 7). Moscow: INFRA-M.

/11/ Bashkatov, M. J., Galkova, E. V. (2017). Blockchain at the peak of HYIP: legal risks And opportunities $B 70$ (pp. 24-25). M.: Ed. House of Higher School of Economics.

/12/ Ruchkina, G. F., Berezin, M. Y., Demchenko, M. V. (2019). The implementation and practical application of modern financial technologies: legal regulation: monograph (pp. 16). M.: INFRA-M.

/13/ Naishul, V. (1996). Friedrich August von Hayek, Geoffrey wood. Private money (pp. 16). Publisher "Institute of the National Model of Economics"

M.

114/ Kazantsev, N. M., et al. (2009). Law and Financial (pp. 33). Institute of legislation and comparative law under the Government of the Russian Federation. -M.: Eksmo.

/15/ Kostyukov, A. N. (2002). Discussion questions of the subject and system of Russian financial law: textbook (pp. 27-28). Omsk. 